\title{
STRATEGI ANGGARAN MODAL BERKELANJUTAN UNTUK DESA WISATA MLOKO SEWU
}

\author{
Elana Era Yusdita ${ }^{1}$ \\ Universitas PGRI Madiun \\ elaradita@unipma.ac.id \\ Nurhuda $^{3}$ \\ Universitas PGRI Madiun \\ noerhuda35@gmail.com
}

\author{
Herlin Rosalina Febriyanti² \\ Universitas PGRI Madiun \\ herlinfebriyanti29@gmail.com
}

Handoko Endro Seputro
Universitas PGRI Madiun
handokoeess@gmail.com

\begin{abstract}
ABSTRAK
Tujuan artikel ini untuk menemukan strategi penganggaran modal yang berasal dari hibah pemerintah untuk desa wisata Mloko Sewu. Metode yang digunakan adalah kualitatif konstruktif. Hasil yang didapatkan dari analisis kebutuhan desa wisata adalah konsep anggaran berdasarkan estimasian perkembangan arus kas masuk dan keluar dalam rentang waktu yang sempit untuk keberlanjutan pengadaan sarana dan prasarana. Cara ini dipandang sesuai dengan sumber pendanaan yang tidak berasal dari investor, tidak diniatkan untuk balik modal, dan hanya ada dana terbatas untuk modal.
\end{abstract}

Kata Kunci: struktur modal; rencana belanja; dana hibah; pengabdian masyarakat

\section{ABSTRACT}

The purpose of this article is to find a capital budgeting strategy derived from government grants for the tourist village of Mloko Sewu. The method used is qualitative constructive. The results obtained from the analysis of rural tourism needs are budget concepts based on estimates of the development of cash flows in and out in a narrow time span for the sustainability of the procurement of facilities and infrastructure. This method is considered in accordance with funding sources that do not come from investors, not intended to achieve return on investment, and there is only limited funds for capital.

Keywords: $\quad$ capital structure; expenditure plan; village development grant; community service

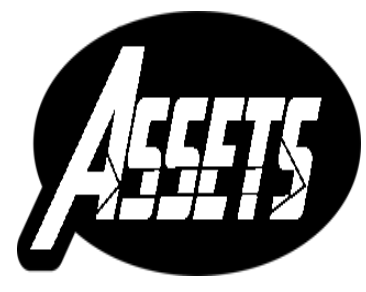

ASSETS

Jurnal Akuntansi dan Pendidikan

Vol. 7 No. 2

Hlmn. 129 - 140

Madiun, Oktober 2018 p-ISSN: 2302-6251 e-ISSN: 2477-4995

Artikel masuk: 19 Oktober 2018 Tanggal diterima: 31 Oktober 2018 


\section{PENDAHULUAN}

Tim Program Hibah Dana Desa (PHBD) Universitas PGRI Madiun mendapatkan hibah dana desa untuk membuka desa wisata Mloko Sewu. Dana yang didapatkan tidak dapat digunakan untuk membangun sebuah desa wisata dengan sarana dan prasarana lengkap menurut analisis peta konsep (Lampiran 1) dan dana yang diterima. Dana yang turun lebih kecil daripada saat pengajuan, sedangkan kebutuhan mendesak lainnya seperti dana pembangunan mushola dan pembukaan lahan parkir masih belum bisa diatasi. Padahal salah satu unsur dari Sapta Pesona, yaitu menciptakan kenangan bagi wisatawan, melibatkan pelayanan dan sarana di tempat wisata (Atmoko, 2014). Oleh karena itu, tim PHBD yang terdiri dari sebelas mahasiswa BEM dan seorang dosen pendidikan akuntansi berusaha menyusun anggaran awal saat pengajuan proposal berdasarkan prioritas pembangunan, lalu merencanakan belanja modal susulan dalam sebuah anggaran berkelanjutan.

Metode penganggaran yang selama ini sering digunakan seperti payback period, accounting rate of return, net present value, rate of return merupakan metode pengambilan keputusan untuk rencana investasi (Mowen, Hansen, \& Heitger, 2014). Metode ini diperuntukkan untuk memperhitungkan balik modal, sedangkan dana hibah PHBD digunakan tidak untuk dikembalikan. Selain itu, jika kita berpatokan pada penganggaran pada UMKM, jenis usaha ini cenderung tidak memakai sistem penganggaran yang baik (Wahyudi \& Fattah, 2017). Salah satu penyebab kesulitan pengusaha UMKM tidak menerapkan metode tertentu adalah tidak dibuatnya laporan keuangan (Nurfitriani \& Suryawati, 2017).

Penelitian di bidang wisata, sejauh ini belum ada yang menyinggung perhitungan kebutuhan sarana dan prasarana maupun teknik penganggarannya (misalnya Satria, 2009; Sidiq \& Resnawaty, 2014; Suharto, 2016). Senada dengan itu, di bidang akuntansi maupun manajemen belum terdapat pembahasan anggaran modal untuk pembangunan desa wisata, walaupun pembahasan ada di bidang yang paling mendekati yaitu penganggaran pada wirausaha dan UMKM (misalnya Nurfitriani \& Suryawati, 2017; Wahyudi \& Fattah, 2017). Kalaupun ada tulisan membahas manajemen keuangan di bidang pariwisata, tidak ada praktik kongkrit dalam hal penerapannya (misalnya Bhaskar, 2015).

Oleh karena itu, penulis mengajukan metode alternatif pembuatan anggaran dengan bertahap sesuai dengan pertumbuhan pengunjung sebagai dasar arus kas masuk dan fasilitas yang dibutuhkan sebagai dasar arus kas keluar. Artikel ini bertujuan untuk menemukan strategi penganggaran modal yang berasal dari hibah pemerintah untuk desa wisata Mloko Sewu. Pemahaman atas ilmu penganggaran yang terbatas bagi masyarakat diharapkan dapat disederhanakan karena dana hibah akan kembali pada pengelolanya, bukan pada pemberi hibah.

\section{METODE PENELITIAN}

Metodologi yang dipilih adalah kualitatif. Pengajuan metode baru anggaran untuk pengelolaan dana hibah desa wisata merupakan konstruksi praktik akuntansi. Sebagaimana yang disampaikan oleh Morgan (1988), praktisi dalam bidang akuntansi bukan hanya menguasai praktiknya saja, tapi mereka dapat memilih apa yang harus ditampilkan. Apalagi praktik akuntansi khususnya dalam kasus ini, penganggaran modal, tidak dapat lepas dari kondisi tempat ia diterapkan (Atmadja, 2013). Keberpihakan tim PHBD sebagai perancang anggaran, kondisi desa wisata, dan terbatasnya dana hibah merupakan asal mula dari penciptaan metode anggaran baru. Tim PHBD terdiri dari 1 orang ketua dan 10 orang anggota yang berasal dari Badan Eksekutif Mahasiswa berbagai angkatan, serta 1 orang dosen sebagai pembimbing. 
Penyusunan anggaran ini dimulai saat penyusunan proposal hibah oleh tim Badan Eksekutif Mahasiswa Universitas PGRI Madiun kepada Kemenristekdikti RI, yaitu pada bulan Februari 2018. Penerapan realisasi anggaran sesuai hibah yang lolos dimulai pada Mei 2018 (semester pertama tahun pertama) dan direncanakan berjalan hingga 2019. Metode yang diterapkan adalah wawancara untuk mengetahui masalah awal, observasi lokasi desa wisata, dan partisipasi tim bersama masyarakat, hingga menghasilkan sebuah konsep penganggaran modal. Wawancara dan observasi dimulai secara informal pada saat beberapa anggota BEM berlibur ke Mloko Sewu, sebelum penyusunan proposal yaitu pada Januari 2018, kepada salah satu tokoh masyarakat penggerak sadar wisata yang saat itu hanya bisa mendirikan gubug dan meletakkan kotak amal. Setelah mengetahui ada permasalahan, wawancara dilanjutkan untuk mengetahui potensi wisata kepada penduduk sekitar yang memang ingin membangun desa wisata pada setiap kali kunjungan mahasiswa untuk camping pada akhir pekan. Pada Februari 2018, saat proposal utuh jadi, tim PHBD mulai secara formal menemui kepala desa dan perwakilan Perhutani di Desa Pupus untuk memperoleh persetujuan karena wilayah Mloko Sewu yang secara administratif masuk Desa Pupus, namun hutannya berada di bawah Perhutani. Partisipasi berbagai pihak tersebut akhirnya dilakukan dengan menggunakan whatsapp sampai saat ini karena jauhnya jarak kampus dan lokasi desa wisata. Kunjungan mahasiswa ke lokasi hanya dapat dilakukan pada akhir pekan.

\section{HASIL PENELITIAN DAN PEMBAHASAN}

\section{Asal Mula Dana Hibah Bina Desa}

Mloko Sewu merupakan salah satu wilayah di Desa Pupus, Kecamatan Ngebel, Kabupaten Ponorogo, Propinsi Jawa Timur. Selama ini, Telaga Ngebel yang berada di bawah bukit Mloko Sewu telah dikenal dan menjadi objek wisata sekaligus lapangan pekerjaan bagi masyarakat sekitar. Tidak banyak orang yang mengetahui potensi bukit Mloko Sewu yang menyuguhkan pemandangan Telaga Ngebel dan hijaunya hutan. Sedikitnya pengunjung membuat tokoh masyarakat desa tersebut berusaha promosi dan membangun tempat wisata dengan swadaya masyarakat. Kemandirian masyarakat selama ini belum terfasilitasi karena keterbatasan dana dan ilmu.

Sebuah tim yang dibentuk dari Badan Eksekutif Mahasiswa Universitas PGRI Madiun memiliki solusi mendapatkan dana dengan mengikutkan potensi Mloko Sewu dalam Program Hibah Bina Desa 2018 yang didanai oleh Kemenristekdikti RI. Sejumlah dana yang cair tak dapat serta merta dibelanjakan untuk keseluruhan pembangunan desa wisata. Pengelolaan desa wisata yang baik harus mencakup pengelolaan atas sumber daya wisata, pemasaran, manajemen SDM, dan manajemen konflik (Purmada, Wilopo, \& Hakim, 2016). Semua ini tertuang dalam pariwisata berbasis komunitas.

Konsep pembangunan wisata berkelanjutan didasarkan pada pariwisata berbasis komunitas menggagas peran masyarakat untuk ikut serta dalam pembangunan tempat wisata sebagai pelaku, bukan sasaran pembangunan (Purnamasari, 2011). Hal ini menjadi salah satu penentu cukupnya dana hibah untuk menciptakan sebuah dana wisata yang ideal. Kriteria pariwisata berbasis masyarakat terdiri dari tiga unsur, yaitu ekonomi, sosial-budaya, dan lingkungan (Purnamasari, 2011). Lebih jauh dijelaskan, unsur ekonomi terdiri dari terbukanya lapangan pekerjaan dengan kegiatan ekonomi baru, tanpa meniadakan aktivitas ekonomi yang sudah ada, dapat tercipta hubungan ekonomi antarsektor, dapat memberikan manfaat dan menaikkan taraf hidup pada masyarakat lokal, memberi kontribusi untuk kegiatan 
masyarakat, menyediakan pasar untuk melibatkan masyarakat dalam promosi barang dan jasa wisata, serta peningkatan kualitas infrastruktur dan fasilitas umum.

Unsur penganggaran investasi tempat wisata yang harus dipikirkan adalah struktur, ukuran, pola, dan tipe investasi (Bhaskar, 2015). Atas dasar tersebut dan rencana hibah yang hanya mendanai pembangunan beberapa sarana, maka perlu dipikirkan prioritas pembangunan. Dasar pemilihan tingkat prioritas adalah sarana yang dapat menghasilkan aliran kas masuk, yaitu objek utama yang mengundang pengunjung untuk datang. Dengan pertimbangan keindahan alam, kebutuhan perpustakaan, dan distribusi hasil bumi khas Mloko Sewu, maka diputuskan ada tiga sarana utama yang dibangun. Pertama, berdasarkan hasil wawancara salah satu anggota tim PHBD kepada masyarakat desa, diketahui hanya terdapat satu perpustakaan di SD untuk delapan desa. Gagasan untuk menjawab kebutuhan ini adalah perpustakaan terbuka (living library). Perpustakaan dibuat di atas pohon sekaligus berfungsi menarik pengunjung. Kedua, photo corner yang terbuat dari daur ulang sampah, khususnya wadah minum yang ditinggalkan wisatawan di lokasi wisata. Hal ini berdasarkan observasi tim PHBD yang sebelum pengajuan proposal hibah, gemar berkemah di Mloko Sewu. Ketiga, Mloko Sewu store yang diharapkan dapat menampung hasil bumi sekitar tempat wisata untuk menjadi buah tangan pengunjung. Berdasarkan observasi dan wawancara tim PHBD, komoditas tanaman di Mloko Sewu adalah kopi mentah maupun olahan, bunga, kacang-kacangan, lemon. Bunga dari pepohonan yang dapat dimanfaatkan untuk cinderamata adalah pinus. Masyarakat juga memproduksi pupuk. Berdasarkan klasifikasi oleh-oleh dan kebutuhan masyarakat untuk makan dan minum, maka direncanakan ada 3 toko yang masing-masing menjual oleh-oleh makanan mentah, makanan siap saji, serta cinderamata berbentuk hiasan dan hasil olahan lebih lanjut misalnya pupuk dan bunga hias.

Tim PHBD memutuskan membangun ketiga jenis sarana itu saat dana hibah diterima dengan rincian anggaran pada lampiran 1. Ide ini merupakan buah pikir tim PHBD. Sosialisasi kepada masyarakat baru dilakukan setelah anggaran disetujui dan proposal lolos seleksi. Pada saat perencanaan anggaran awal, tim PHBD juga mendata kebutuhan dan sarana lain yang belum dapat direalisasi menggunakan dana hibah. Setelah mengetahui kebutuhan tersebut, model anggaran berkelanjutan disusun.

\section{Perpustakaan Terbuka}

Sarana yang dibangun berkaitan dengan sarana belajar dan eksplorasi keindahan Mloko Sewu adalah rumah pohon dalam sebuah konsep bernama living library atau perpustakaan terbuka. Kebutuhan pendanaan rumah pohon terbagi menjadi tiga, yaitu pembangunan rumah pohon, penyediaan buku, dan pengelolaan perpustakaan. Untuk pembangunan rumah pohon anggaran yang tersedia adalah sebesar Rp8.499.000,-. Dana tersebut diharapkan menjadi 2 buah rumah pohon. Biaya ini merupakan 24\% dari keseluruhan dana (lihat lampiran 1). Gambar 1 menunjukkan rancangan rumah pohon dan gambar 2 merupakan hasil pembangunan.

Unsur kedua dalam living library adalah buku yang diperoleh dengan cara membuka penggalangan donasi. Tim PHBD menciptakan dua jalur donasi yaitu dengan menyebarkan flayer donasi via media sosial dan yang kedua dengan bekerja sama dengan yayasan penyalur donasi buku serta Pos Indonesia untuk memudahkan calon donatur seluruh Indonesia untuk menyalurkan donasinya tanpa ongkos kirim. 


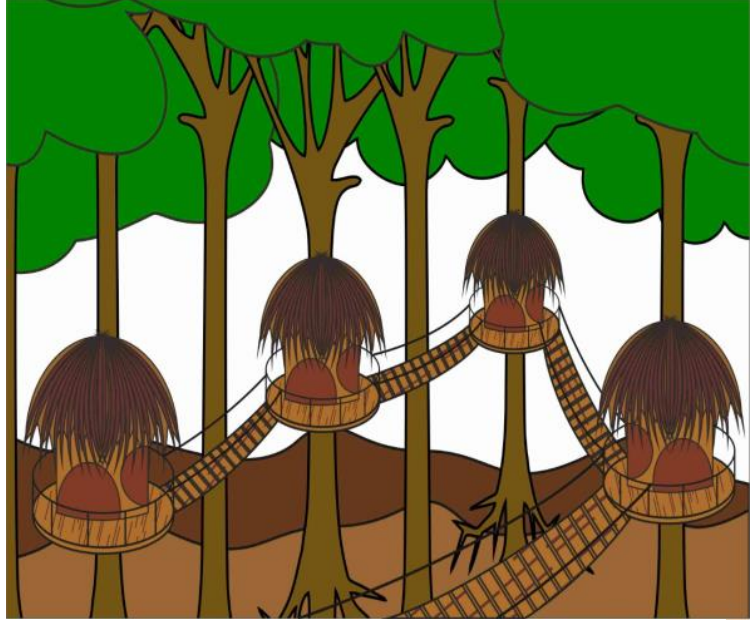

Gambar 1. Rencana Rumah Pohon

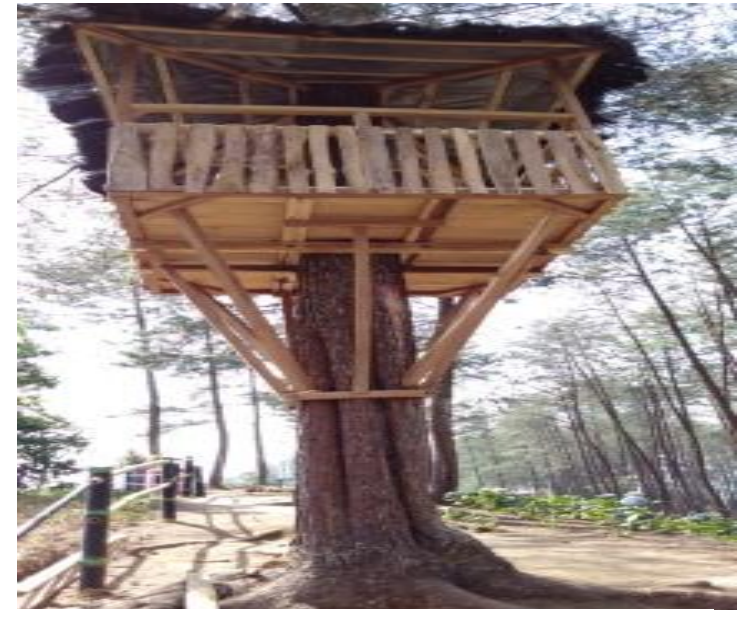

Gambar 2. Realisasi Rumah Pohon

Unsur ketiga dalam living library adalah pengelolaan perpustakaan yang terdiri dari kebersihan, perawatan buku, dan pengawasan pengunjung. Kebersihan perpustakaan serta perawatan buku dari rayap dan kotoran harus dilakukan oleh masyarakat secara piket. Saat ini dana yang tersedia tidak memungkinkan untuk menggaji petugas piket khusus living library. Sedangkan untuk pengawasan buku dari tindakan perusakan dan pencurian oleh pengunjung tidak dapat dilakukan oleh petugas piket secara terus menerus, mengingat penduduk sekitar juga menjadi petani. Oleh karena itu, diharapkan ke depannya pengelola Mloko Sewu dapat membeli kamera CCTV untuk mengawasi pengunjung. Pengelolaan living library membutuhkan penyisihan arus kas masuk di masa mendatang untuk gaji petugas piket dan pembelian CCTV.

\section{Photo Corner}

Sarana kedua yang dibangun adalah pembuatan photo corner Mloko Sewu yang diharapkan jadi icon wisata. Dana yang dibutuhkan untuk pembuatan icon dan photo corner ini adalah sebesar Rp2.710.000,- (lihat lampiran 1). Dana ini merupakan 7,74\% dari dana keseluruhan dengan hasil yang diharapkan sebagaimana yang tercantum pada gambar 3. Realisasi photo corner terdapat pada gambar 4, sedangkan icon wisata Mloko Sewu masih dalam proses pembangunan.

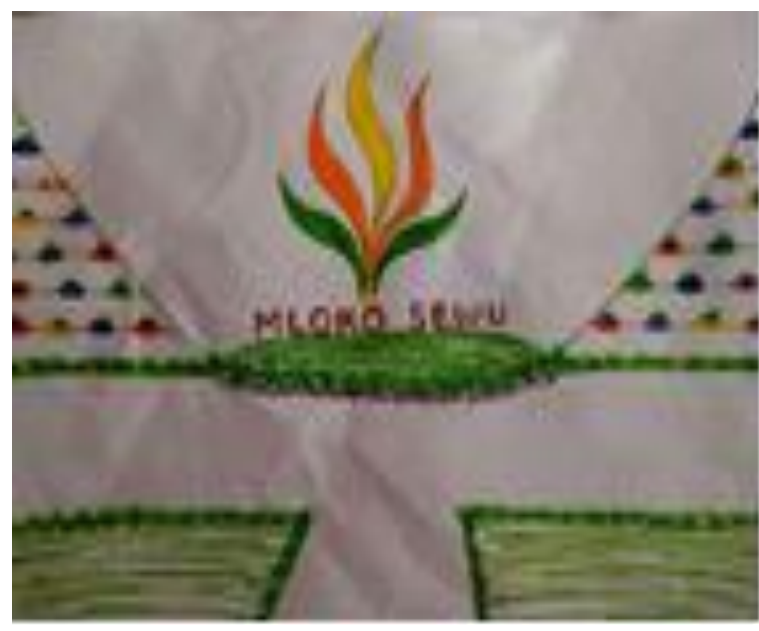

Gambar 3. Rencana Photo Corner Mloko Sewu

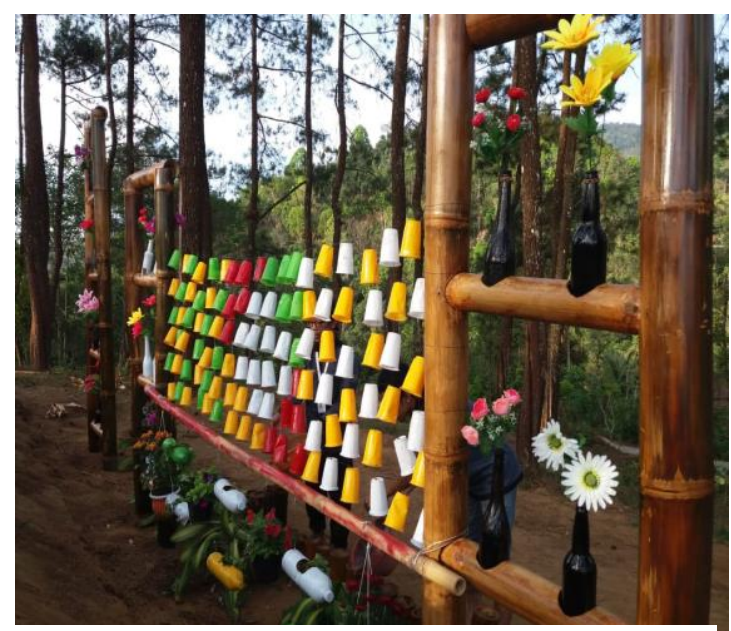

Gambar 4. Realisasi Photo Corner 
Pembuatan photo corner melibatkan bahan bangunan, bunga, dan sampah botol plastik. Dana anggaran di atas hanya digunakan untuk membeli bahan bangunan dan bunga. Pada tahap awal, tim PHBD mengumpulkan sampah botol bekas untuk dihias dan dimanfaatkan untuk menjadi spot foto. Untuk tahap pengembangan spot foto, pengunjung direncanakan akan dilibatkan dalam aktivitas daur ulang sampah. Sampah yang dimanfaatkan diperoleh dari pengunjung itu sendiri dan masyarakat desa sekitar. Kebutuhan yang belum bisa dipenuhi dari anggaran dana tersebut adalah gaji untuk pengawas spot foto dan perawat taman.

\section{Mloko Sewu Store}

Sarana yang dibangun untuk menampung hasil bumi masyarakat sekaligus tempat wisatawan membeli makanan dan minuman bernama Mloko Sewu Store. Dana untuk membangun 3 toko bertemakan bangunan tradisional adalah sebesar Rp7.986.000,-, yang merupakan 22,82\% dari dana hibah keseluruhan (lihat lampiran 1). Rencana bentuk Mloko Sewu store ada pada gambar 5 dan realisasi terdapat pada gambar 6.

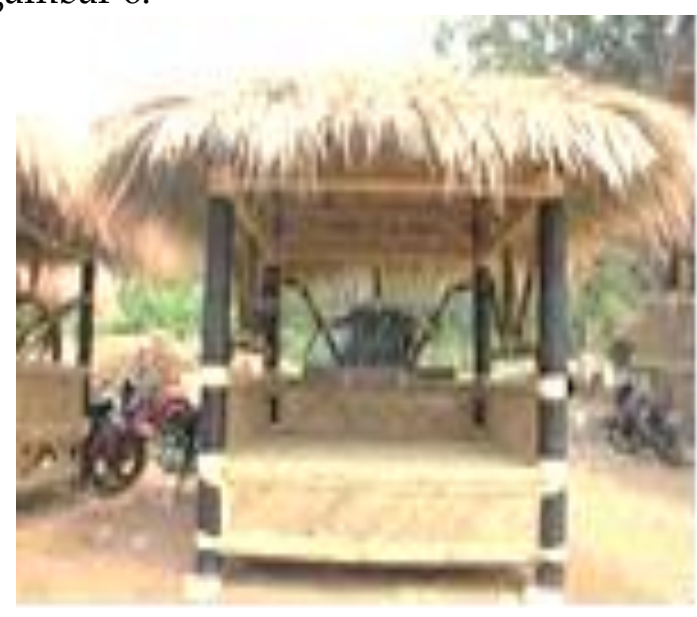

Gambar 5. Rencana Mloko Sewu Store

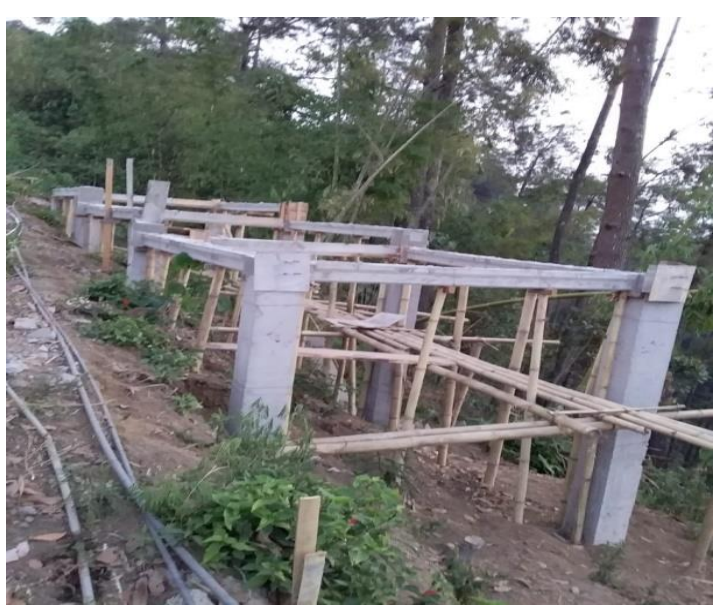

Gambar 6. Realisasi Mloko Sewu Store

Mloko Sewu store ini terbagi menjadi 3 jenis barang dagangan, yaitu pertama, bahan mentah dan oleh-oleh berupa hasil pertanian dan perkebunan khas Mloko Sewu, seperti tanaman hias, bunga, sampai pupuk. Kedua, bahan jadi dan siap konsumsi, seperti kopi yang siap seduh dan jeruk. Ketiga, makanan dan minuman untuk pengunjung yang sekaligus menjadi tempat istirahat.

Pengelolaan ketiga kios ini membutuhkan tenaga untuk pengawasan kios dari kerusakan, serta pencatatan penggunaan listrik dan air untuk masing-masing toko. Jika memungkinkan, di masa mendatang pengelola dapat menyediakan meteran listrik per kios untuk memudahkan pengelola dalam mengawasi penggunaan listrik. Selain itu, tidak ada bangunan yang dapat menjadi kios penjual tiket masuk sehingga untuk tahun pertama pengelola dapat memanfaatkan Mloko Sewu store sekaligus untuk tempat berjualan tiket masuk. Sarana dan prasarana lain yang perlu dipikirkan adalah pengadaan mushola, kamar mandi/WC yang layak termasuk dengan biaya air dan kebersihannya, tempat parkir mobil dan sepeda motor, sampai dengan perbaikan jalan untuk kenyamanan pengunjung.

Tim PHBD memprediksikan pengunjung yang datang akan meningkat setelah adanya icon wisata Mloko Sewu. Pengunjung ini terbagi menjadi dua jenis, yaitu pengunjung biasa dan yang camping. Arus kas masuk objek wisata dapat terbagi menjadi tiga, berasal dari parkir, tiket masuk, dan penjualan merchandise di Mloko 
Sewu store. Penjualan tiket masuk antara pengunjung biasa dan camping akan dibedakan. Ada kekhawatiran pengunjung tidak tertarik berkunjung setelah diberlakukan tiket masuk, sehingga tim PHBD mengatur strategi gratis tiket masuk pada semester pertama setelah pembangunan selesai. Estimasinya adalah sebagai berikut:

Tabel 1. Estimasi laba semester pertama tahun pertama dalam satuan bulan

\begin{tabular}{llr}
\hline \multicolumn{1}{c}{ Uraian } & \multicolumn{2}{c}{ Total } \\
\hline Tiket masuk & $\mathrm{Rp}$ & $0,-$ \\
\hline Dana PHBD (yang dipakai pembangunan minus publikasi) & $\mathrm{Rp}$ & $32.143 .000,-$ \\
\hline Swadaya masyarakat & $\mathrm{Rp}$ & $500.000,-$ \\
\hline Total pendapatan & $\mathrm{Rp}$ & $32.643 .000,-$ \\
\hline Pembangunan fasilitas & $\mathrm{Rp}$ & $32.143 .000,-$ \\
\hline Listrik dan air & $\mathrm{Rp}$ & $500.000,-$ \\
\hline Total biaya & $\mathrm{Rp}$ & $(32.643 .000,-)$ \\
\hline Laba operasional & $\mathrm{Rp}$ & $0,-$ \\
\hline
\end{tabular}

Tahun pertama semester pertama diharapkan menjadi tahun pengadaan sarana dan prasarana Mloko Sewu. Pengadaan sarana dan prasarana berasal dari dana hibah, maka yang perlu diperhatikan adalah efisiensi dan efektifitas penggunaan dana. Sebagian besar bahan baku harus membeli, sedangkan biaya tenaga kerja diusahakan menjadi nol rupiah dengan kerjasama antara tim PHBD yang terdiri dari mahasiswa dengan masyarakat sekitar. Pembayaran tagihan listrik dan air pada masa ini masih mengandalkan swadaya masyarakat karena tiket masuk masih gratis. Sedangkan tenaga pengawas masih tak berbayar. Masyarakat diprediksikan belum melakukan banyak pengawasan karena sebanding dengan tingkat pengunjung yang masih sedikit, ditambah dengan aktivitas bertani dan berkebun yang menjadi pekerjaan utama yang tidak mungkin ditinggalkan oleh penduduk. Oleh karena itu, diprediksikan laba operasional masih nol rupiah.

Pada semester selanjutnya, prediksi jumlah pengunjung ada peningkatan karena usaha promosi sosial media ditempuh oleh tim melalui facebook, instagram, youtube, penyebaran pamflet. Selain itu, tim PHBD memanfaatkan promosi mulut ke mulut untuk menciptakan image positif terhadap suatu merk (Pamungkas \& Zuhroh, 2016; Rahayu, 2014). Apalagi didukung dengan zaman serba internet, dialog antarkonsumen dapat tercipta dari sosial media (Kotler \& Amstrong, 2012). Caranya adalah dengan testimoni dan tag foto di instagram, sehingga akan meminimalisasi penggunaan iklan berbayar yang belum tentu efektif meningkatkan pengunjung (Yusdita, 2016).

Tiket masuk pengunjung akan dibedakan menjadi dua jenis, yaitu tiket masuk biasa dan untuk pengunjung yang camping. Tiket masuk biasa dihargai Rp 7.000,dengan perkiraan 100 orang pengunjung per minggu. Tiket pengunjung yang ingin camping (bermalam) di dihargai Rp 12.000,- dengan estimasi ada setidaknya 50 orang dalam sebulan yang menginap di Mloko Sewu. Pendapatan dari pengunjung ini setidaknya dapat membayar biaya listrik, air, dan perawatan fasilitas Mloko Sewu yang dibangun pada semester pertama tahun pertama. Pengelola diharapkan dapat menyisihkan Rp 2.400.000,- per bulan selama 6 bulan berturut-turut untuk belanja alat seperti CCTV untuk bantuan mengawasi rumah pohon, pembangunan mushola. Pada semester ini, pengelola juga diharapkan dapat membayar biaya listrik dan air tanpa mengharapkan swadaya dari masyarakat. Desa wisata Mloko Sewu diharapkan dapat 
membiayai pengeluarannya sendiri pada masa ini, namun belum bisa menggaji pengawas dan pegawai lainnya dalam pengelolaan.

Tabel 2. Estimasi laba semester kedua tahun pertama dalam satuan bulan

\begin{tabular}{|c|c|c|}
\hline \multirow[t]{2}{*}{ Perhitungan } & \multicolumn{2}{|r|}{ Total } \\
\hline & & \\
\hline Rp 7.000,- x 100 orang/minggu x 4 minggu & $\mathrm{Rp}$ & $2.800 .000,-$ \\
\hline Tiket masuk camping $\mathrm{Rp} 12.000,-\times 50$ orang/bulan & $\mathrm{Rp}$ & 600.000,- \\
\hline Dana PHBD & $\mathrm{Rp}$ & $0,-$ \\
\hline Swadaya masyarakat & $\mathrm{Rp}$ & $0,-$ \\
\hline Total pendapatan & $\mathrm{Rp}$ & 3.400.000,- \\
\hline Biaya: & & \\
\hline Pembangunan fasilitas dan belanja alat & $\mathrm{Rp}$ & $2.400 .000,-$ \\
\hline Listrik dan air, perawatan & $\mathrm{Rp}$ & 1.000.000,- \\
\hline Total biaya & $\mathrm{Rp}$ & $(3.400 .000,-)$ \\
\hline Laba operasional & $\mathrm{Rp}$ & $0,-$ \\
\hline
\end{tabular}

Pada semester pertama tahun kedua, tiket masuk diharapkan dapat dibagi menjadi tiga jenis untuk semakin menarik pengunjung, yaitu tiket masuk biasa untuk orang dewasa seharga Rp 10.000,- dan tiket masuk biasa untuk anak-anak seharga Rp 5.000,-, sedangkan untuk tiket masuk camping tetap pada kisaran Rp 12.000,-Pendapatan dari semester ini digunakan untuk perawatan dan pembayaran listrik dan air yang diprediksikan meningkat seiring meningkatnya pengunjung jika dibandingkan dengan semester pertama tahun pertama. Pemasukan juga diprediksikan dapat digunakan untuk pembayaran gaji ticketing dan pengawas yang dapat dilakukan oleh masyarakat secara bergilir. Dari perhitungan pendapatan dan biaya tersebut, diharapkan ada laba operasional sebesar Rp 1.200.000,-. Laba operasional Rp 1.200.000,- per bulan selama 1 semester itu ditujukan untuk ditabung untuk membuat sarana yang lebih besar, misalnya mushola yang lebih besar dan layak.

Tabel 3. Estimasi laba semester pertama tahun kedua dalam satuan bulan

\begin{tabular}{|c|c|c|c|}
\hline \multirow{2}{*}{$\begin{array}{r}\text { Rincian } \\
\text { Pendapatan: }\end{array}$} & \multirow[t]{2}{*}{ Perhitungan } & \multicolumn{2}{|r|}{ Total } \\
\hline & & & \\
\hline Tiket masuk biasa & Rp $10.000,-x 150$ orang/minggu $\times 4$ minggu & $\mathrm{Rp}$ & 6.000 .000 \\
\hline Tiket masuk anak & Rp 5.000,- $\times 20$ orang/minggu $\times 4$ minggu & $\mathrm{Rp}$ & 400.000 \\
\hline Tiket masuk camping & Rp $12.000,-x 50$ orang/bulan & $\mathrm{Rp}$ & 600.000 \\
\hline Dana PHBD & & $\mathrm{Rp}$ & $0,-$ \\
\hline Swadaya masyarakat & & $\mathrm{Rp}$ & $0,-$ \\
\hline Total pendapatan & & $\mathrm{Rp}$ & $7.000 .000,-$ \\
\hline Biaya: & & & \\
\hline Pembangunan fasilitas & & $\mathrm{Rp}$ & $0,-$ \\
\hline Listrik dan air, perawat & & $\mathrm{Rp}$ & 1.000.000, \\
\hline Gaji ticketing & Rp 5.000,- $\times 10$ jam $\times 4$ minggu $\times 14$ orang & $\mathrm{Rp}$ & $2.800 .000,-$ \\
\hline Pengawas & Rp $100.000,-x 20$ orang & $\mathrm{Rp}$ & $2.000 .000,-$ \\
\hline Total biaya & & $\mathrm{Rp}$ & $\begin{array}{r}(5.800 .000, \\
-)\end{array}$ \\
\hline Laba operasional & & $\mathrm{Rp}$ & 1.200 .000$, \\
\hline
\end{tabular}




\section{SIMPULAN}

Konsep penganggaran yang dapat diterapkan untuk dana hibah adalah estimasian perkembangan arus kas masuk dan keluar. Arus kas masuk dapat didasarkan pada perkembangan jumlah pengunjung, sedangkan arus kas keluar diestimasi dari kebutuhan sarana dan prasarana masa mendatang. Konsep titik impas dan metode lainnya sulit diterapkan karena sebuah usaha kadang tidak mementingkan laba, namun diniatkan menghidupi para pekerjanya. Keterbatasan konsep ini adalah adanya pengawasan terhadap realisasi anggaran yang hanya bermodalkan foto whatsapp, kunjungan di akhir pekan, dan masyarakat yang belum mengenal nota untuk pertanggungjawaban dana.

\section{DAFTAR PUSTAKA}

Atmadja, A. T. (2013). Pergulatan Metodologi dan Penelitian Kualitatif Dalam Ranah Ilmu Akuntansi. Jurnal Akuntansi Profesi, 3(2), 122-141.

Atmoko, T. P. H. (2014). Strategi Pengembangan Potensi Desa Wisata Brajan Kabupaten Sleman. Jurnal Media Wisata, 12(2), 146-154.

Bhaskar, G. (2015). Role of Financial Management in Tourism. International Journal of Business Intelligence, 1(1), 1-3.

Kotler, P., \& Amstrong, G. (2012). Prinsip-Prinsip Pemasaran (13th ed.). Jakarta: Erlangga.

Morgan, G. (1988). Accounting As Reality Construction: Towards A New Epistemology For Accounting Practice. Accounting Organizations and Society, 13(5), 477-485.

Nurfitriani, A. F., \& Suryawati, R. F. (2017). Faktor-Faktor yang Memengaruhi Penerapan Payback Period sebagai Teknik Penganggaran Modal pada UMKM di Kota Bogor. Jurnal Manajemen Dan Organisasi, VIII(2), 89-102.

Pamungkas, B. A., \& Zuhroh, S. (2016). Pengaruh Promosi di Media Sosial dan Word of Mouth Terhadap Keputusan Pembelian (Studi Kasus Pada Kedai Bontacos, Jombang). Jurnal Komunikasi, X(2), 145-169.

Rahayu, D. D. (2014). Pengaruh Word of Mouth dan Brand Community Komunitas Sepak Bola di Pekanbaru Terhadap Brand Image. Jurnal Ekonomi, 22(1), 1-16.

Satria, D. (2009). Strategi Pengembangan Ekowisata Berbasis Ekonomi Lokal Dalam Rangka Program Pengentasan Kemiskinan Di Wilayah Kabupaten Malang. Journal of Indonesian Applied Economics, 3(1).

Sidiq, A. J., \& Resnawaty, R. (2014). Masyarakat Lokal Di Desa Wisata Linggarjati. In Prosiding KS: RISET \& PKM (Vol. 4, pp. 38-44).

Suharto, B. (2016). Strategi Pengembangan Wisata Agro di Banyuwangi. Jurnal Ilmiah Pariwisata, 21(1).

Wahyudi, S., \& Fattah, F. A. (2017). Keputusan Penganggaran Modal Pada Usaha Mikro Kecil Menengah di Sukoharjo. In Prosiding Seminar Pendidikan Ekonomi dan Bisnis. Universitas Sebelas Maret Surakarta.

Yusdita, E. E. (2016). Periklanan Dalam Implementasi Strategi dan Implikasinya Pada Kinerja Keuangan Perusahaan Consumer Goods di Indonesia. ASSETS : Jurnal Akuntansi dan Pendidikan, 5(1), 73-88. 


\section{LAMPIRAN 1. PETA KONSEP KEBUTUHAN DESA WISATA}

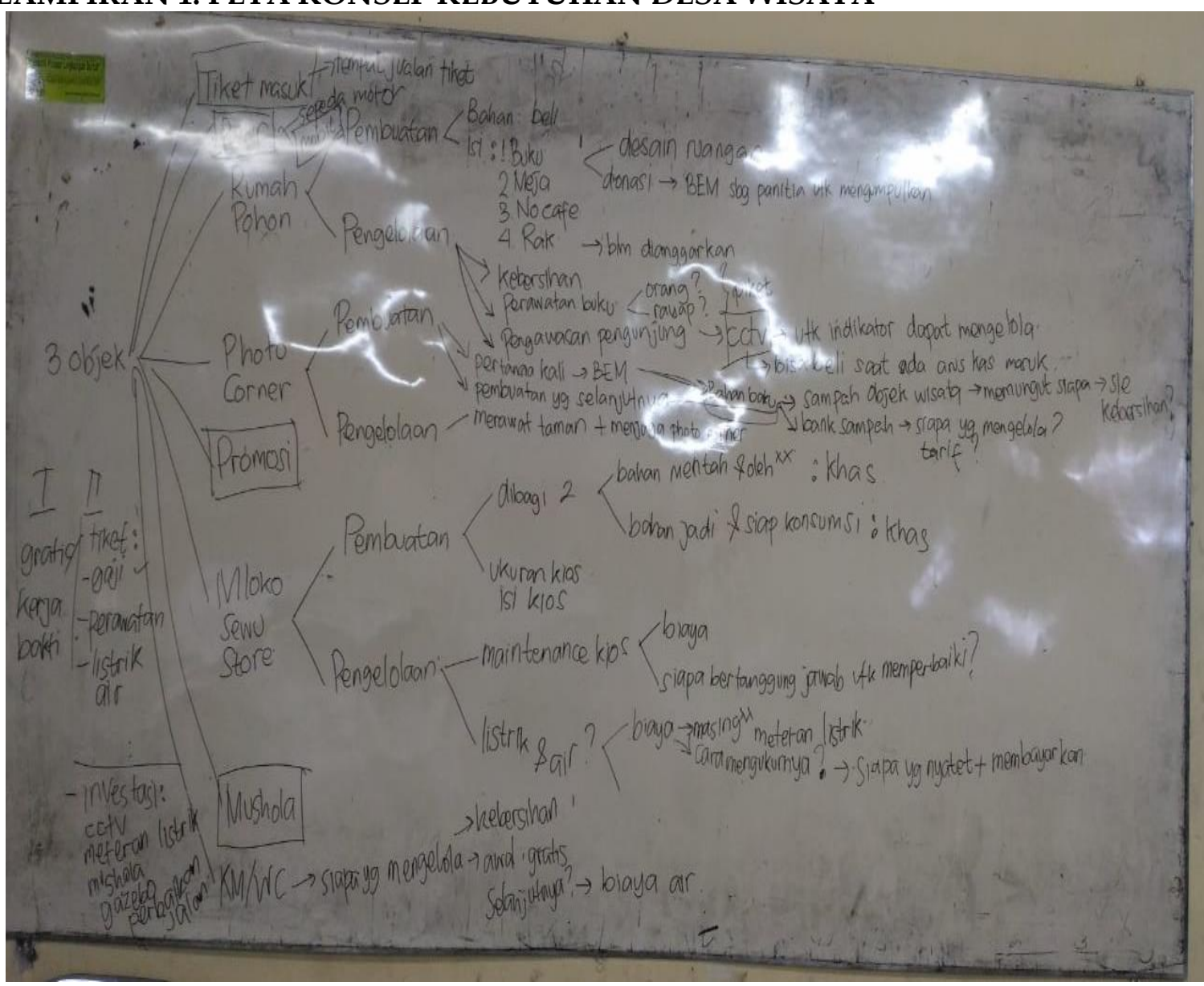

LAMPIRAN 2. ESTIMASI PEMAKAIAN DANA HIBAH BINA DESA

\begin{tabular}{|c|c|c|c|c|c|}
\hline $\mathrm{No}$ & Uraian & Kuantitas & Satuan & Biaya (Rp) & Jumlah (Rp) \\
\hline \multicolumn{6}{|c|}{ BAHAN HABIS PAKAI } \\
\hline \multicolumn{6}{|c|}{ a. Pembuatan rumah pohon } \\
\hline 1 & Kayu balok & 30 & Buah & 80.000 & 2.400 .000 \\
\hline 2 & Papan kayu & 40 & Buah & 60.000 & 2.400 .000 \\
\hline 3 & Triplek & 10 & Buah & 100.000 & 1.000 .000 \\
\hline 4 & Kaca polos & 4 & Buah & 150.000 & 600.000 \\
\hline 5 & Bambu & 10 & Buah & 20.000 & 200.000 \\
\hline 6 & Paku (campur) & 5 & $\mathrm{Kg}$ & 25.000 & 125.000 \\
\hline 7 & Mur \& baut $(10 \& 20 \mathrm{~cm})$ & 50 & Buah & 7.000 & 350.000 \\
\hline 9 & Kawat (campur) & 5 & Roll & 25.000 & 125.000 \\
\hline 10 & Tali tambang & 8 & Roll & 150.000 & 1.200 .000 \\
\hline 11 & Plitur & 7 & Liter & 40.000 & 280.000 \\
\hline 12 & Pernis & 7 & Liter & 60.000 & 420.000 \\
\hline 13 & Kuas & 5 & Buah & 15.000 & 75.000 \\
\hline 14 & Ijuk & 8 & Roll & 30.000 & 240.000 \\
\hline 15 & Terpal & 2 & Buah & 130.000 & 260.000 \\
\hline 16 & Tiner & 3 & Liter & 8.000 & 24.000 \\
\hline \multicolumn{5}{|c|}{ Sub jumlah } & 8.499 .000 \\
\hline \multicolumn{6}{|c|}{ b. Pembuatan photo corner } \\
\hline 1 & Fiber glass & - & - & 2.000 .000 & 2.000 .000 \\
\hline
\end{tabular}




\begin{tabular}{|c|c|c|c|c|c|}
\hline 2 & Cat air & 5 & Liter & 40.000 & 200.000 \\
\hline 4 & Kawat (campur) & 10 & Roll & 25.000 & 250.000 \\
\hline 5 & Bambu & 7 & Buah & 20.000 & 140.000 \\
\hline 6 & Ijuk & 4 & Roll & 30.000 & 120.000 \\
\hline \multicolumn{4}{|c|}{ Sub jumlah } & & 2.710 .000 \\
\hline \multicolumn{6}{|c|}{ c. Mloko sewu store } \\
\hline 1 & Kayu balok & 60 & Buah & 80.000 & 4.800 .000 \\
\hline 2 & Bambu & 30 & Buah & 20.000 & 600.000 \\
\hline 3 & Ijuk & 30 & Roll & 30.000 & 90.000 \\
\hline 4 & Bilik/tikar bambu & 20 & Roll & 73.600 & 1.472 .000 \\
\hline 5 & Terpal & 3 & Buah & 130.000 & 390.000 \\
\hline 6 & Paku (campur) & 5 & $\mathrm{Kg}$ & 25.000 & 125.000 \\
\hline 7 & Kawat (campur) & 5 & Roll & 25.000 & 125.000 \\
\hline 8 & Plitur & 3 & Liter & 40.000 & 120.000 \\
\hline 9 & $\begin{array}{l}\text { Papan kayu (tebal } 2 \\
\mathrm{~cm} / 3 \mathrm{~cm} / 15 \mathrm{~cm})\end{array}$ & 6 & Ikat & 40.000 & 240.000 \\
\hline 10 & Tiner & 3 & Liter & 8.000 & 24.000 \\
\hline \multicolumn{5}{|c|}{ Sub jumlah } & 7.986 .000 \\
\hline \multicolumn{6}{|c|}{ PERALATAN PENUNJANG } \\
\hline & Gergaji & 2 & Buah & 50.000 & 100.000 \\
\hline & Palu & 2 & Buah & 45.000 & 90.000 \\
\hline & Tatah & 2 & Buah & 20.000 & 40.000 \\
\hline & Mesin bor & 1 & Buah & 250.000 & 250.000 \\
\hline & Amplas & 10 & Buah & 10.000 & 100.000 \\
\hline & Konsumsi (6x) & 200 & Buah & 8.500 & 1.700 .000 \\
\hline & $\begin{array}{l}\text { Burning laporan akhir } \\
\text { (CD/DVD) }\end{array}$ & 3 & Buah & 45.000 & 135.000 \\
\hline & $\begin{array}{l}\text { Kaos kepanitiaan (BEM } \\
\text { \& organisasi Mloko } \\
\text { Sewu) }\end{array}$ & 52 & Buah & 80.000 & 4.160 .000 \\
\hline
\end{tabular}

\begin{tabular}{|c|c|c|c|c|c|}
\hline \multicolumn{5}{|c|}{ Sub jumlah } & 6.575 .000 \\
\hline \multicolumn{6}{|c|}{ PERJALANAN } \\
\hline 1 & $\begin{array}{l}\text { Perjalanan ke Desa } \\
\text { Pupus-Madiun (MOU- } \\
\text { Monitoring dan } \\
\text { Evaluasi) }\end{array}$ & 12 & Kali & 100.000 & 1.200 .000 \\
\hline 2 & $\begin{array}{l}\text { Perjalanan belanja } \\
\text { keperluan material }\end{array}$ & 2 & Kali & 25.000 & 50.000 \\
\hline 3 & $\begin{array}{l}\text { Perjalanan ke seminar } \\
\text { dan publikasi ( } 5 \text { orang) }\end{array}$ & 1 & Kali & 300.000 & 1.500 .000 \\
\hline \multicolumn{5}{|c|}{ Sub jumlah } & 2.750 .000 \\
\hline \multicolumn{6}{|c|}{ PUBLIKASI JURNAL DAN SEMINAR NASIONAL } \\
\hline 1 & Cetak poster PHBD & 3 & Eks & 75.000 & 225.000 \\
\hline 2 & Dokumentasi & 2 & Kali & 60.000 & 120.000 \\
\hline 3 & Film pendek & 2 & Kali & 75.000 & 150.000 \\
\hline 4 & Biaya submit jurnal & 2 & Paket & 750.000 & 1.500 .000 \\
\hline 5 & $\begin{array}{l}\text { Biaya pendaftaran } \\
\text { seminar }\end{array}$ & 2 & Kali & 500.000 & 1.000 .000 \\
\hline 6 & Cetak poster smart & 3 & Eks & 75.000 & 225.000 \\
\hline
\end{tabular}


YUSDITA, E. E., FEBRIYANTI, H. R., NURHUDA \& SEPUTRO, H. E. STRATEGI ANGGARAN MODAL ....

\begin{tabular}{llllrr}
\hline \multicolumn{7}{c}{ branding } & & & \\
\hline 7 & $\begin{array}{l}\text { Cetak x-banner smart } \\
\text { branding }\end{array}$ & 3 & Eks & 120.000 & 360.000 \\
\hline 8 & Cetak katalog wisata & 3 & Eks & 350.000 & 1.050 .000 \\
\hline 9 & Liputan Jawa Pos & 1 & Kali & 500.000 & 500.000 \\
\hline 10 & Laporan akhir & 10 & Eks & 15.000 & 150.000 \\
\hline \multicolumn{7}{c}{ Sub jumlah } \\
\hline & Jumlah & & 5.280 .000 \\
\hline
\end{tabular}

